\title{
LogForum
}

$>$ Scientific Journal of Logistics <

$2019,15(4), 449-457$

http://www.logforum.net

p-ISSN $1895-2038$

e-ISSN 1734-459X

ORIGINAL PAPER

\section{SELECTED APPLICATIONS OF METAL NANOPARTICLES IN MEDICINE AND PHARMACOLOGY}

\author{
Renata Dobrucka \\ Poznan University of Economics and Business, Poznan, Poland
}

\begin{abstract}
Background: Nanotechnology is a field of science and technology that has been developing rapidly for several decades. It is considered to be one of the major activity areas of the scientific, technological and innovation sectors. The use of innovative technologies enables the modification and production of nanomaterials with new or enhanced properties. Metal nanoparticles are different from their bulk counterparts, and they have become the subject of growing attention due to their unique characteristics caused by their different size as well as their potential applications.

Methods: As a result, they are used in many different areas of life. This work presents the most important examples of metal nanoparticle applications in pharmacology, cancer therapy and stomatology.

Results and conclusion: Nanotechnology makes it possible to quickly transform the results of basic research into successful innovations, and develop leading technologies whose results can be implemented in large international groups of companies and small businesses in all sectors of the economy. As such actions require a properly functioning supply chain, the development and implementation of nanotechnology products will not reach the appropriate level without the proper logistics.
\end{abstract}

Key words: metal nanoparticles, medicine, pharmacology, cancer therapy.

\section{DEFINITION OF METAL NANOPARTICLES}

A nanometer is equal to one billionth of a meter. Nanomaterials are a group of structures in which at least one dimension falls within the range of 1 to $100 \mathrm{~nm}$ [Olawoyin 2018]. One of the interesting issues in the field of nanotechnology is metal nanoparticles. Depending on their origin and chemical composition, there are natural nanoparticles, nanoparticles obtained as a result of human activity, as well as unintentional nanoparticles defined as by-products of nanotechnological processes [Kargozar, Mozafari 2018].

In general, nanoparticles are divided into three main groups: one-dimensional, twodimensional and three-dimensional. Nanoparticle structure can be characterized by a random arrangement of atoms. Nanoparticles with an ordered structure are single crystals or crystal clusters. Some nanoparticles are incorporated in the structure of other metals. A 1D, 2D or 3D nanoparticle has a specific orientation towards the surrounding metal [Kelsall 2009]. The most common 3D nanostructures are nanoparticles whose crosssection does not exceed the length of $100 \mathrm{~nm}$ at any point. They may differ in shape but in most cases, they are spherical or oval. 3D structures also include dendritic structures, nanocones, nanoposts and nanoflowers. If the length of all three sides, e.g. of a hexahedron, is several $\mathrm{nm}$, such a system becomes a zerodimensional system [0D], often called a "quantum dot". The distribution of density of states is no longer continuous and it consists of a number of energy levels [as in the case of atoms or molecules] that correspond to the 
successive quantum numbers and gradually higher energies.

Quantum dots are nanostructural semiconductor systems that consist of atoms $12-16$ and $13-15$ of the periodic table. Single dots are made of a core that consists of 100100000 atoms, mainly cadmium telluride or selenide with semiconductor properties. The core is surrounded by a protective layer of zinc sulfide, to which various ligands may be attached, such as nucleic acids, proteins and antibodies that show affinity for specific structures in the organism [Rzeszutek et al. 2014]. The photoluminescence of quantum dots depends on their size, so it is relatively easy to obtain dots that emit electromagnetic radiation with different wavelengths [Dwiecki et al. 2014]. They are also characterized by relatively narrow photoluminescence emission bands, a high quantum capacity, and a long life of fluorescence and stability [Galian and de la Guardia, 2009]. Polymer dots are cross-linked or aggregated with a polymer produced from a monomer or a linear polymer. This kind of dots is created as a result of an aggregation of the carbon core with polymer chains [Zhang et al. 2011; Gao et al., 2013].

Nanoparticles are characterized by a great chemical diversity. The majority of them are metal oxides, metals, silicone compounds, varieties of carbon or ceramic materials. They can also have significantly different shapes. Monometallic nanoparticles have the form of hexahedrons, tetrahedrons, octahedrons, truncated octahedrons, icosahedrons, concave hexahedrons, rods, spheres, whiskers, rice grains and even stars. Their usable forms include powders, suspensions, solutions and gels [colloids].

Due to their size, metal nanoparticles have different properties than larger particles made of the same material. They also show various levels of order throughout the volume of the material they form. They can form ordered crystal structures, amorphous bodies or vitreous bodies composed of unorganized atoms. Nanoparticles with a crystal structure can be single crystals, or they can be composed of randomly arranged crystals or grains, which influence the physical properties of the material [Suwanboon, Chukamnerd 2007].

\section{METAL NANOPARTICLES IN PHARMACOLOGY}

As microorganisms quickly become immune to antibiotics, many scientists are looking for new antibacterial substances. It is also more difficult to fight various kinds of viruses. A combination of medicines and nanoparticles has proven to be an effective way to address the most resistant viruses and bacteria. Studies carried out by Shahverdi [2007] showed that the combination of nanosilver with antibiotics intensifies the effects of antibacterial medicines, such as amoxicillin, erythromycin, clindamycin, penicillin $G$ and vancomycin. The results obtained by Suganya et al. [2015] suggest that nanosilver may be the key element in treating AIDS patients. The authors tested the antibacterial effects of biologically synthesized silver nanoparticles against strains obtained from patients infected with HIV. The nanosilver was synthesized with the use of spirulina. The studies showed that silver nanoparticles effectively inhibited the replication of HIV-1. The combination of spirulina and nanosilver turned out to be even more effective against the virus.

Nanosilver is also used as an antibacterial agent in the production of bandages, dressings and surgical masks. A nanosilver coating on prostheses and medical equipment ensures long antibacterial activity due to the slow release of silver ions [Darouiche et al.1990, Leaper 2006].

Copper oxide nanoparticles actively combat hospital-acquired infections as well as the influenza A virus and SARS virus [Ren et al., 2009]. $\mathrm{TiO}_{2}$ nanoparticles, thanks to their photocatalytic properties, can be found in preparations for disinfecting surgical instruments, catheters or surfaces made of transparent materials. $\mathrm{TiO}_{2}$ nanoparticles used with nanofillers exhibited bactericidal effects on Escherichia coli and fungicidal effects on Candida albicans [Kosmala and Szymańska 2016] after incubation in visible light for 24 hours. Due to their physico-chemical properties, $\mathrm{TiO}_{2}$ nanoparticles are applied in dermatology in order to treat such conditions as juvenile acne or atopic dermatitis [Świdwińska-Gajewska, Czerczak 2014]. 
Nanoparticles are more and more often used as systems that transport various kinds of active substances to specific body tissues. Nanoparticles improve the pharmacodynamic and pharmacokinetic parameters of medicines, such as bioavailability and time of release of the active substance, and they extend the period of pharmacological activity. Their small size allows nanoparticles to efficiently move within the body, and make it more difficult for the immune system to detect the medicines. Over the past few years, more attention has been paid to the nanoscale systems for administering medicines, mainly due to their excellent biocompatibility, the ability to reach a specific place in the body, as well as their nanosize [Zhou et al. 2005]. The large surface facilitates the binding of ligands that recognize the receptors of target cells, which makes it possible to transport medicines to specific cells. Nanoparticles serve as carriers of therapeutic substances that enable a targeted therapy thanks to combination with ligands, which bind with specific receptors on the surface of the affected cells, and are also used in imaging examinations to detect lesions of disease. For this reason, nanoparticles are perfect for diagnosing and treating various diseases, which allows earlier detection of pathological changes and more effective treatment of patients [Wang, Thanou 2010].

The treatment of neurodegenerative diseases can also make use of nanoparticles bound with antioxidant particles, such as cerium oxide. The currently used antioxidants remove only a small part of redundant oxygen forms; unfortunately, also from those places where their quantity is appropriate. Nanotechnology makes it possible to create particles that would control the scavenging of free radicals by themselves on the basis of redox potential, i.e. particles that would act only where necessary [Singh et al. 2007].

\section{METAL NANOPARTICLES IN CANCER TERAPHY}

Nanoparticles have an enormous significance and are becoming more and more important in the treatment of cancer. The studies on silver particles, which have been conducted for many years, lead to a conclusion that such particles can be used in cancer treatment [Cryer, Thorley 2019]. Gynecological oncology implements the AgNORs [argyrophylic nucleolar organizer regions] method, which consists of the singlestage colloidal silver coating of nucleolus organizer regions to assess cell ploidy and proliferation [Bańkiewicz et al. 2005].

Nanoparticles used as contrast agents play an enormous role in cancer diagnosis. Imaging with the use of nanoparticles is more effective than imaging with the use of standard contrast agents. This stems from the numerous advantages of nanoparticles, such as their small size, optical properties, and the ability to accumulate in the area of the tumor thanks to the EPR effect [Gao et al. 2004, Gaucher et al. 2005]. Multi-functional nanoparticles are of considerable significance because they can be combined with diagnostic agents and contain therapeutic compounds, making it possible to simultaneously image and treat tumors [Wang et al. 2008]. This is caused mainly by the fact that the functionalization of the nanoparticle surface with the appropriate bioparticles [e.g. antibodies] enables them to circulate within the body even for several days, and selectively accumulate in specific areas of the body (cancer cells).

The recent years have witnessed a considerable progress in the development of nanoparticle systems that improve the imaging and diagnosis of cancer by means of MRI [Sun et al. 2008, Shubayev et al. 2009, Veiseh et al. 2010]. The use of nanoparticles in MRI results in a greater contrast, which improves the discrimination between pathologically changed tissues and healthy tissues. Iron nanoparticles have been subjected to comprehensive examinations concerning the possibility of using them to improve the contrast of MRI [Hao et al. 2010]. As presented by the latest studies on hybrid preparations with a superparamagnetic iron oxide core, modifications with external coatings and functional sensors have been developed in such a way as to enable the increase of contrast in alternative imaging techniques other than MRI.

Gold nanoparticles conjugated with antibodies - antibody epidermal growth factor receptor [EGFR] - seem to be a promising 
diagnostic tool for cancer cells. The appropriate functionalization with antibodies EGFR - causes colloidal gold nanoparticles to change SPR peaks, which may be used to differentiate between malignant and benign cells [El-Sayed et al. 2005]. Another way to functionalize gold nanoparticles is to flatten them in order to achieve better internalization and binding with cells. Apart from a polymer, a fluorescent dye can be added. The added dye makes it possible to trace the path of gold nanoparticles to the selected cells [Tiwari et al. 2011].

Targeted cancer therapy is becoming a quickly developing area of both clinical and preclinical studies. The mechanism of operation of targeted medicines involves inhibiting specific signal transmission paths for cancer development processes: infiltration, proliferation, angiogenesis and formation of metastases [Duchnowska 2007]. The specific delivery of medicines to cancer cells with the use of nanoparticles can be affected in two ways: by releasing therapeutics from nanoparticles extracellularly to the microenvironment of the tumor [passive transport], or by releasing medicines inside the cell through endocytosis (active transport) [Xia 2010].

Metal nanoparticles are also used in radiotherapy. One example of this is gold particles. Gold nanoparticles are used to support radiotherapy because of their ability to absorb radiation. Nanogold accumulates in the location of the tumor and absorbs ionizing radiation, making it possible to administer smaller therapeutic doses, thereby protecting healthy tissues. The studies carried out by Hainfeld et al. [2008] showed that gold nanoparticles did not inhibit the growth of cancer lesions, while radiation only slowed down the growth of the tumor. However, radiation performed immediately after the administration of gold nanoparticles resulted in a considerable reduction of the size of the tumor or its total eradication.

Gold nanoparticles are also used in hypothermia, i.e. a non-invasive cancer treatment method. Due to the supply of gold nanoparticles, cancer cells are exposed to temperatures that are higher than usual, which leads to their destruction. Gold nanoparticles make it possible to convert laser light into heat; irradiation with laser increases the temperature around gold nanoparticles, which breaks the cancer cell membrane. Heat is produced as a result of, among other things, electron phonon and phonon - phonon interactions. In addition, therapy at higher temperatures is related to cytotoxicity in the environment with a low $\mathrm{pH}$ and low oxygenation. Such conditions are found in cancer cells, but not in healthy ones, so only cancer cells die [Koperkiewicz 2015].

Under the influence of UV radiation or ultrasound, $\mathrm{TiO}_{2}$ nanoparticles become able to destroy cancer cells. UV light can damage cancer cells and their surroundings. The in vivo studies on glioma cells carried out by Yamaguchi's scientific group [2010] showed the effectiveness of $\mathrm{TiO}_{2}$ nanoparticles in photodynamic therapy. A similar effect on glioma cells was exhibited by $\mathrm{TiO}_{2}$ nanoparticles created by means of ultrasound [Yamaguchi et al. 2011].

\section{METAL NANOPARTICLES IN STOMATOLOGY}

Another significant area in which nanotechnology is applied is the production of dental implants. Nanoparticles are widely used mainly for preparing the surface of implants with geometry in the nanometric scale, and for producing coatings with better adhesive properties. They are also applied as fillers in dental materials. The addition of $\mathrm{TiO}_{2}$ nanoparticles to dental prostheses increases their bactericidal properties. The activation of $\mathrm{TiO}_{2}$ nanoparticles leads to the formation of reactive oxygen forms; however, this process requires light. Photoactivation of prostheses can be carried out outside the oral cavity, e.g. at night, when the prosthesis is not in use. It is a comfortable, safe and hygienic solution for people who wear prostheses [Kosmala, Szymańska, 2016]

Implantology is constantly looking for solutions to accelerate and improve osseointegration and minimize the risk of infection and implant rejection [Wiatr, Niwakowska 2013]. Sugita et al. [2011] 
studied the effects of coating an implant surface with a layer that contains titanium dioxide nanoparticles. The results showed that the application of a very thin coating causes a diametrical change to the biological properties of implants, while the morphology of the implant surface remains unchanged. Dental implants are exposed to damage caused by the accumulation of bacterial biofilm. At present, it is becoming increasingly more common to modify implant surfaces with nanoparticles. The use of a nanoparticle coating on an implant surface protects it against infections over a longer period of time. Flores et al. [2010] observed that the application of iron to titanium coatings had an antibacterial effect on Pseudomonas aeruginosa. Such a reaction positively affects the healing process and minimizes the risk of implant rejection.

The application of a gold nanoparticle coating on titanium implant surfaces led to the regeneration of bones. The studies showed that the presence of gold nanoparticles on titanium surfaces significantly improved the differentiation of osteogenic cells and influenced bone regeneration $[\mathrm{Heo}$ et al. 2016].

Abdulkareem's research group [2015] coated titanium surfaces with layers of $\mathrm{ZnO}$ nanoparticles, hydroxyapatite and a combination of $\mathrm{ZnO}$ with hydroxyapatite. After 96 hours of incubation, the scientists observed that the amounts of anaerobic bacteria and Streptococcus spp. were reduced on all examined surfaces. The best results were obtained for the surface on which a layer of $\mathrm{ZnO}$ nanoparticles and hydroxyapatite was applied. The obtained results led to the conclusion that an implant coating covered with a layer of metal nanoparticles provides effective antibacterial protection and reduces the risk of infection. The results proved the benefits associated with the use of composites, which can act synergistically to offer effective antimicrobial protection.

The development of a bacterial biofilm is a process that consists of many stages and starts at the moment of the first contact between the material and body fluids. Macroparticulate ingredients of body fluids quickly adsorb on the surface of biomaterial and create a conditioning layer that changes the nature of the surface of the implant. Such biofilms are often resistant to traditional antibacterial agents. The creation of a bacterial biofilm on the surface of teeth, i.e. dental plaque, plays an important role in the pathogenesis of parodontium diseases. A very promising solution is to develop filling materials that contain antibacterial substances which would hinder the development of bacteria. Wu's research group [2015], using dimethylaminohexadecyl methacrylate [DMAHDM] as the filler along with calcium phosphate nanoparticles, developed selfhealing composites that can be widely applied in dentistry. Zhang et al. [2012] developed a binding agent that has a cidal effect on bacterial biofilms by combining quaternary ammonium dimethacrylate [QADM] and silver nanoparticles. The combination of silver nanoparticles and quaternary ammonium dimethacrylate [QADM] also improved the strength of the binding agent.

Li et al. [2014] developed binding agents created by combining [DMADDM] and silver nanoparticles. The developed agents significantly inhibited the growth of a biofilm. Such a combination offers a wide spectrum of possibilities of using it both as an antibacterial and anti-caries agent. The studies carried out by Zhang et al. in 2013 proved that the application of two antibacterial agents, i.e. 12methacryloyloxydodecylpyridinium bromide [MDPB] and silver nanoparticles, improved the strength properties of dentine and reduced biofilms on the dental plaque. Such a combination can be successfully applied while developing binding agents and sealing materials, as well as composites and cements that hinder the development of biofilms and caries.

\section{CONCLUSIONS}

Nanotechnology is a new research approach related to understanding and improving the properties of matter on a nano scale. On that scale, matter exhibits completely different and surprising properties, which blur the traditional boundaries between scientific and technical disciplines. The solutions offered by 
nanotechnology are widely used in medicine. This work has presented the most important examples of metal nanoparticle applications in pharmacology, cancer therapy and stomatology.

At present, science shows that nanotechnology has become a key to a wider spectrum of technologies and therapeutic methods. Nanotechnology gives rise to new questions and leads to new connections that will have an enormous impact on the future of medicine.

\section{ACKNOWLEDGMENTS AND FUNDING SOURCE DECLARATION}

Research on synthesis financed from grant for young researchers in 2016 of the Ministry of Science and Higher Education.

Conflict of interest: The author declares that they have no conflicts of interest.

\section{REFERENCES}

Abdulkareem E.H., Memarzadeh K., Allaker R.P., Huang J., Pratten J.,Spratt D., 2015. Anti-biofilm activity of zinc oxide and hydroxyapatite nanoparticles as dental implant coating materials. Journal of dentistry, $\quad 43[12], \quad 1462-1469$. http://doi.org/10.1016/j.jdent.2015.10.010

Bieńkiewicz A., Korczyński J., Gottwald L., Danilewicz M., 2005. The assessment of argyrophylic nucleolar organizer regions [AgNORs] in gynecological oncology [Zastosowanie oceny stref organizatorów $\mathrm{j}^{1}$ derkowych (AgNORs) w onkologii ginekologicznej]. Menopause Review, 4[1], 28-32.

Cryer A.M., Thorley A.J., 2019. Nanotechnology in the diagnosis and treatment of lung cancer. Pharmacology \& therapeutics, 198, 189-205.

http://doi.org/10.1016/j.pharmthera.2019.02 .010
Darouiche R.O., Raad I.I., Heard S.O., Thornby J.I., Wenker O.C., Gabrielli A., Harris R.L. 1999. A comparison of two antimicrobial-impregnated central venous catheters. New England Journal of Medicine, 340[1], 1-8.

http://doi.org/10.1056/NEJM199901073400 $\underline{101}$

Duchnowska R., Medyczny W.I., 2007. Targeted therapy-new hopes in the treatment of breast cancer [Leczenie celowane-nowe nadzieje w leczeniu raka piersi.]. Oncology in Clinical Practice, 3 [3], 128-134.

Dwiecki K., Nogala-Kalucka M., Polewski K., 2014. Application of quantum dots for the determination of food ingredients and contaminants [Zastosowanie kropek kwantowych do oznaczania składników i zanieczyszczeń żywności]. Food Science Technology Quality, 21 [3]. http://doi.org/10.15193/zntj/2014/94/005$\underline{013}$

El-Sayed I.H., Huang X., El-Sayed M.A., 2005. Surface plazmon resonance scattering and absorption of anti-EGFR antibody conjugated gold nanoparticles in cancer diagnostics: Applications in oral cancer. Nano Letters, 5[5]: 829-34. http://doi.org/10.1021/n1050074e

Flores C.Y., Diaz C., Rubert A., Benitez G.A., Moreno M.S., Fernandez Lorenzo de Male M.A., Salvarezza R.C., Shilardi P.L., Vericat C, 2010. Spontaneous adsorption of silver nanoparticles on $\mathrm{Ti} / \mathrm{TiO}_{2}$ surfaces. Antibacterial effect on Pseudomonas aeruginosa. J. Colloid Interface Sci., 15, 350, 402-408.

http://doi.org/10.1016/j.jcis.2010.06.052

Galian R.E., de la Guardia M., 2009. The use of quantum dots in organic chemistry. Trends Anal. Chem., 28 [3], 279-291. http://doi.org/10.1016/j.trac.2008.12.001

Gao M.X., Liu C.F., Wu Z.L., Zeng Q.L., Yang X.X., Wu W.B., Huang C.Z. 2013. A surfactant-assisted redox hydrothermal route to prepare highly photoluminescentcarbon quantum dots with aggregation-induced emission enhancement properties. Chemical Communications, 49[73], 8015-8017. 


\section{http://doi.org/10.1039/C3CC44624G}

Gao X., Cui Y., Levenson R.M., Chung L.W., Nie S. 2004. In vivo cancer targeting and imaging with semiconductor quantum dots. Nature biotechnology, 22[8], 969-976. http://doi.org/10.1038/nbt994

Gaucher G., Dufresne M.H., Sant V.P., Kang N., Maysinger D., Leroux J.C. 2005. Block copolymer micelles: preparation, characterrization and application in drug delivery. Journal of controlled release, 109[1], 169188.

http://doi.org/10.1016/j.jconrel.2005.09.034

Hainfeld J.F., Dilmanian F.A., Slatkin D.N., Smilowitz H.M., 2008. Radiotherapy enhancement with gold nanoparticles. Journal of Pharmacy and Pharmacology, 60[8], 977-985.

http://doi.org/10.1211/jpp.60.8.0005

Hao R., Xing R., Xu Z., Hou Y., Gao S., Sun S., 2010. Synthesis, functionalization, and biomedical applications of multifunctional magnetic nanoparticles. Advanced Materials, 22[25], 2729-2742. http://doi.org/10.1002/adma.201000260

Heo D.N., Ko W.K., Lee H.R., Lee S.J., Lee D., Um S.H., Kwon I.K., 2016. Titanium dental implants surface-immobilized with gold nanoparticles as osteoinductive agents for rapid osseointegration. Journal of colloid and interface science, 469, 129-137. http://doi.org/10.1016/j.jcis.2016.02.022

Kelsall R.W., Hamley I.W., Geoghegan M., 2009. Nanotechnologie. [Nanotechnology]] PWN, Warszawa 2009, 5.

Kosmala K., Szymańska R. 2016. Nanoparticles of titanium oxide [IV]. preparation,

properties and application [Nanocząstki tlenku tytanu (IV). otrzymywanie, właściwości i zastosowanie.]. Kosmos, 65 [2], 235-245.

Koperkiewicz D., 2015. Gold nanoparticles in photothermal anti-cancer therapy [Nanocząstki złota $\mathrm{w}$ fototermicznej terapii antynowotworowej], ISSN2082 1107, 1 [21], 56-66.

Kargozar S., Mozafari M., 2018. Nanotechnology and Nanomedicine: Start small, think big. Materials Today: Proceedings, 5[7], 15492-15500. http://doi.org/10.1016/j.matpr.2018.04.155

Leaper D.J., 2006. Silver dressings: their role in wound management. International wound journal, 3[4], 282-294.

http://doi.org/10.1111/j.1742$\underline{\text { 481X.2006.00265.X }}$

Li F., Weir M.D., Fouad A.F., Xu H.H., 2014. Effect of salivary pellicle on antibacterial activity of novel antibacterial dental adhesives using a dental plaque microcosm biofilm model. Dental Materials, 30[2], 182-191.

http://doi.org/10.1016/j.dental.2013.11.004

Olawoyin R., 2018. Nanotechnology: The future of fire safety. Safety science, 110, 214-221.

http://doi.org/10.1016/j.ssci.2018.08.016

Ren G., Hu D., Cheng E.W., Vargas-Reus M.A., Reip P., Allaker R.P., 2009. Characterisation of copper oxide nanoparticles for antimicrobial applications. International journal of antimicrobial agents, 33[6], 587-590.

http://doi.org/10.1016/j.ijantimicag.2008.12 .004

Rzeszutek J., Matysiak M., Czajka M., Sawicki K., Rachubik P., Kruszewski M., KapkaSkrzypczak L., 2014. Application of nanoparticles and nanomaterials in medicine [Zastosowanie nanocząstek i nanomateriałów w medycynie]. Hygeia Public Health, 49[3], 449-457.

Singh N., Cohen C.A., Rzigalinski B.A. 2007. Treatment of neurodegenerative disorders with radical nanomedicine. Annals of the New York Academy of Sciences, 1122[1], 219-230. http://doi.org/10.1196/annals.1403.015

Sugita Y., Ishizaki K., Iwasa F., Ueno T., Minamikawa H., Yamada M., Ogawa T. 2011. Effects of pico-to-nanometer-thin $\mathrm{TiO}_{2}$ coating on the biological properties of microroughened titanium. Biomaterials, 32[33], 8374-8384.

http://doi.org/10.1016/j.biomaterials.2011.0 7.077

Sun C., Lee J.S., Zhang M., 2008. Magnetic nanoparticles in MR imaging and drug delivery. Advanced drug delivery reviews, 60[11], 1252-1265. 
http://doi.org/10.1016/j.addr.2008.03.018

Suganya K.U., Govindaraju K., Kumar V.G., Dhas T.S., Karthick V., Singaravelu G., Elanchezhiyan M., 2015. Biomolecular Spectroscopy.Spectrochimica Acta Part A: Molecular and Biomolecular Spectroscopy, 144, 266-272.

Shubayev V.I., Pisanic T.R., Jin S., 2009. Magnetic nanoparticles for theragnostics. Advanced drug delivery reviews, 61[6], 467-477.

http://doi.org/10.1016/j.addr.2009.03.007

Suwanboon S., Chukamnerd S., Anglong U., 2007. Morphological control and optical properties of nanocrystalline $\mathrm{ZnO}$ powder from precipitation method. Songklanakarin Journal of Science \& Technology, 29(6).

Świdwińska-Gajewska A.M., Czerczak S., 2014. Nanoparticles dioxide tytaniumoccupational exposure limits. Occupational Medicine 65, 407-418.

http://doi.org/10.13075/mp.5893.2014.046

Tiwari P.M., Vig K., Dennis V.A., Singh S.R., 2011. Functionalized gold nanoparticles and their biomedical applications. Nanomaterials, $\quad 1[1], \quad 31-63$. http://doi.org/10.3390/nano1010031

Veiseh O., Gunn J.W., Zhang M. 2010. Design and fabrication of magnetic nanoparticles for targeted drug delivery and imaging. Advanced drug delivery reviews, 62[3], 284-304.

http://doi.org/10.1016/j.addr.2009.11.002

Wang X., Yang L., Chen Z.G., Shin D.M., 2008. Application of nanotechnology in cancer therapy and imaging. CA: a cancer journal for clinicians, 58[2], 97-110. http://doi.org/10.3322/CA.2007.0003

Wiatr E., Nowakowska D. 2013. Application of nanoparticles in dental materials - review of the literature. Protet. Stomatological, 63[6], 466-475.

http://doi.org/10.5604/.1133006

Wu J., Weir M.D., Melo M.A.S., Xu H.H., 2015. Development of novel self-healing and antibacterial dental composite containing calcium phosphate nanoparticles. Journal of dentistry, 43[3], 317-326. http://doi.org/10.1016/j.jdent.2015.01.009
Wang M., Thanou M., 2010. Targeting nanoparticles to cancer. Pharmacological Research, 62 [2], 90-99. https://doi.org/10.1016/j.phrs.2010.03.005

Xia W., Low P.S., 2010. Folate-targeted therapies for cancer. Journal of medicinal chemistry, 53[19], 6811-6824. http://doi.org/10.1021/jm100509v

Yamaguchi S., Kobayashi H., Narita T., Kanehira K., Sonezaki S., Kubota Y., Iwasaki Y., 2010. Novel Photodynamic Therapy Using Water-dispersed $\mathrm{TiO}_{2}-$ Polyethylene Glycol Compound: Evaluation of Antitumor Effect on Glioma Cells and Spheroids In Vitro. Photochemistry and photobiology, 86[4], 964-971. http://doi.org/10.1111/j.17511097.2010.00742.x

Yamaguchi S., Kobayashi H., Narita T., Kanehira, K., Sonezaki, S., Kudo, N., Houkin, K. 2011. Sonodynamic therapy using waterdispersed $\quad \mathrm{TiO}_{2}$-polyethylene glycol compound on glioma cells: comparison of cytotoxic mechanism with photodynamic therapy. Ultrasonicssonochemistry, 18[5], 1197-1204.

http://doi.org/10.1016/j.ultsonch.2010.12.0 $\underline{17}$

Zhang K., Melo M.A.S., Cheng L., Weir M.D., Bai Y., Xu H.H. 2012. Effect of quaternary ammonium and silver nanoparticlecontaining adhesives on dentin bond strength and dental plaque microcosm biofilms. Dental Materials, 28[8], 842-852. http://doi.org/10.1016/j.dental.2012.04.027

Zhang K., Cheng L., Imazato S., Antonucci J.M., Lin N.J., Lin-Gibson S., Xu H.H., 2013. Effects of dual antibacterial agents MDPB and nano-silver in primer on microcosm biofilm, cytotoxicity and dentine bond properties. Journal of dentistry, 41[5], 464-474. http://doi.org/10.1016/j.jdent.2013.02.001

Zhang H., Ming H., Lian S., Huang H., Li H., Zhang L., Lee S.T. 2011. Fe2O3/carbon quantum dots complex photocatalysts and their enhanced photocatalytic activity under visible light. Dalton Transactions, 40[41], 10822-10825. http://doi.org/10.1039/C1DT11147G 
Zhou W., Gao P., Shao L., Caruntu D., Yu M., logy, Biology and Medicine, 1[3], 233-237. Chen J., O'Connor C.J. 2005. Drug- loaded, magnetic, hollow silica nanocomposites for

http://doi.org/10.1016/j.nano.2005.06.005 nanomedicine. Nanomedicine: Nanotechno-

\section{PRZYKŁADY ZASTOSOWANIA NANOCZĄSTEK METALI W MEDY- CYNIE I FARMACJI}

STRESZCZENIE. Wstęp: Nanotechnologia jest dziedziną nauki i techniki, która rozwija się intensywnie od kilkudziesięciu lat. Zaliczana jest do jednego z głównych działów aktywności sektora nauki, technologii i innowacji. Zastosowanie innowacyjnych technologii umożliwia modyfikowanie i otrzymywanie nanomateriałow charakteryzujących się zupełnie nowymi lub ulepszonymi właściwościami. Nanocząstki metali stały się przedmiotem uwagi ze względu na ich unikalne właściwości spowodowane różnym rozmiarem oraz potencjalnym zastosowaniem. W efekcie nanocząstki metali znalazły zastosowanie w wielu różnych dziedzinach nauki.

Metody: W niniejszej pracy przedstawiono najważniejsze przykłady zastosowań nanocząstek metali w farmakologii, terapii nowotworowej i stomatologii.

Wyniki i wnioski: Nanotechnologia stwarza możliwości szybkiego przekształcenia wyników badań podstawowych w zakończone sukcesem innowacje oraz opracowanie wiodących technologii, których wyniki można wdrażać w wielkich międzynarodowych koncernach, jak i małych przedsiębiorstwach we wszystkich sektorach gospodarki. W celu realizacji takich działań niezbędny jest prawidłowo funkcjonujący łańcuch dostaw. Zatem rozwój i wdrażanie produktów nanotechnologii bez odpowiedniej logistyki nie mógłoby osiągnąć odpowiednio wysokiego poziomu.

Słowa kluczowe: nanocząstki metali, medycyna, farmacja, terapia nowotworowa

Renata Dobrucka ORCID ID: https://orcid.org/0000-0003-1486-9412

Department of Industrial Products Quality and Ecology

Faculty of Commodity Science

Poznan University of Economics and Business

al. Niepodległości 10, 61-875 Poznan, Poland

e-mail: renata.dobrucka@ue.poznan.pl 